\section{Dragana Nešović1}

University Union "Nikola Tesla" Belgrade

Faculty of Law, Security and Management

"Konstantin Veliki", Niš

\section{Dušan Jerotijević ${ }^{2}$}

University Union "Nikola Tesla" Belgrade

Business and Law Faculty
SCIENTIFIC REVIEW ARTICLE doi:10.5937/ekonomika1803089N

Received: Jun, 13, 2018 Accepted: September, 07, 2018

\title{
ROLE AND IMPORTANCE OF INTERNATIONAL AGREEMENTS IN REGULATING INTERNATIONAL RELATIONS IN MODERN CONDITIONS
}

\begin{abstract}
Abstaract
All international subjects acting on the international scene are obliged to respect generally accepted norms and basic principles of international law.

The basic acts containing these norms on which the international legal system primarily relies are international agreements, whether contracts concluded between states and / or international organizations, bilateral or multilateral. In that respect, starting from the position of international agreements in the generally accepted hierarchy of international law sources, this paper analyses the role of international agreements and the importance that they, as the basic instruments of regulating international relations and cooperation among contemporary subjects of international law, have in the international legal system.

The aim of this paper is to highlight the manner and consequences of the influence on the legal process in this field, given the legal nature of the international agreements impact in the context of varying international relations, under the influence of a omnipresent globalisation.
\end{abstract}

Key words: international agreements, international relations, international subjects, member state, international organization, unification.

JEL Classification: F00, F20, F23.

\section{УЛОГА И ЗНАЧАЈ МЕТУНАРОДНИХ УГОВОРА У РЕГУЛИСАҢУ МЕЪУНАРОДНИХ ОДНОСА У САВРЕМЕНИМ УСЛОВИМА}

\begin{abstract}
Апстракт
Сви међународни субјекти када делују на међунароној сиени дужни су да поштују општеприхваћене норме и основна начела међународног права. Основни акти у којима су садржане ове норме на које се међународни правни

\footnotetext{
${ }^{1}$ dragana.nesovich@gmail.com.

22dusanjerotijevic@gmail.com.
} 
систем првенствено ослања су међународни уговори, било да је реч о уговорима закљученим између држава и/или међународних организаџија, билатерални или мултилатерални.

У вези с тим, а полазећи од позищионирања међународних уговора на лествици општеприхваћене хијерархије извора међународног права, у раду су анализирани улога међународних уговора и значај који они, као основни инструменти регулисања међународних односа и сарадње међу савременим субјектима међународног права, имају у међународном правном систему. Циљ рада је да се укаже на начин и последице юиховог утищаја на правностваралачки процес у овој области с обзиром на правну природу дејства међународних уговора у условима променљивих међународних односа под утииајем свеприсутне глобализације.

Кључне речи: међународни уговори, међународни односи, међународни субјекти, држава чланица, међународна организащија, унификаџија.

\section{Introduction}

International relations are a very broad field of liturgical activities in which different entities operate and in which different, often conflicting or parallel, manifestations are manifested, interests and connections between those entities. Secondly, in the area of international, especially political and economic relations, the only actors are not only sovereign states, but also other international entities such as intergovernmental, supranational and other international organizations (Јеротијевић and Палевић, 2016, p. 142). Especially favorable were the processes of globalization and liberalization in the modern world, where, in the conditions of the existence of a unified world market, the possibilities of national states are reduced to directly encourage the development of their own economy by setting rules that give priority to national organizations. The place of decision-making is often transferred from state to international institutions, which reduces people's ability to influence direct development of government representatives by direct elections.

The rapid and strong integration of national economies into the world economy through trade, finance, technology, information networks and transcultural co-operation has spurred the prosperity of the world as a whole. In the international political and economic relations of the role of states and diplomats, as an instrument of promoting and protecting the interests of countries remains very important, especially in the field of economic relations. The development of various forms of economic cooperation with other countries and the world, the internationalization of their own economy and the operation of their own enterprises, have now become the national strategic interests of each country in full and true sense (Dašić, 2003). However, the benefits of these processes are not distributed either automatically or evenly from country to country. The facts point to a growing polarization between both developed and underdeveloped countries, and within these groups. Some social groups have supernatural benefits, some are only partial, and some suffer.

The most developed countries that base their power on economic superiority, military superiority and production superiority, increasingly shift their foreign policy 
priorities and bind them to the economic sphere, in an effort to realize their interests, among other things, by strong diplomatic economic engagement. Undeveloped countries located at the bottom of the global scale of countries face many problems: insufficient human resources, political instability, poor raw materials, civil wars, high external debt, macroeconomic instability, and so on.

The involvement of developing countries and countries in transition into traditional international institutions (STOs) and various economic integration and trade blocks (EU, NAFTA, ASEAN, ECOWAS, etc.) requires a new model of performance and diplomatic action in order to better protect their economic and political interest in the modern system of international relations where the processes of globalization and integration imply the need for intensive economic diplomatic activity aimed at the realization and protection of economic priorities and interests, in which developing countries and countries in transition can look to the most developed countries and thus manage the foreign diplomatic and external economic activities.

Thus, globalization and liberalization of economic life have led to radical changes in the structure of the priorities of each country's diplomacy, requiring new forms and ways of agreeing and communicating in international frameworks. In the foreground, economic, instead of political priorities, are emerging. Strong diplomatic economic engagement has become an important feature of diplomacy in many countries, and the main preoccupation is how and in what way will provide a better position for the export economy and its companies in the world markets, in order to achieve the most positive effects in economic cooperation with abroad, which or later materialize in appropriate foreign exchange income. In this segment, international agreements play a very important role as one of the most important instruments, by which forms of all forms of cooperation, as well as business relationships with foreign countries are established.

\section{The fact and importance of international treaties}

States are the original subjects of international law, and their contractual capacity is beyond any doubt. In addition to countries, international organizations and their specialized agencies also appear as agents.

For the area of international contract law, the following Convention is of particular importance: the Vienna Convention on the Law of Treaties of 1969, the Vienna Convention on the Succession of States in Relation to the 1978 Treaties and the Vienna Convention on the Law of Treaties between States and International Organizations and between International Organizations from 1986.

International treaties, "as the immediate and strongest manifestation of will" of contemporary subjects of international law, represent the primary sources of law on the basis of which social relations on the international legal scene are formed, unfolded, and stopped (Avramov and Kreća, 2003, p. 51-52 ). Accordingly, international treaties can be defined as legal acts derived from the agreement of the will of "two or more subjects of international law" expressed "by the competent authorities" in order to create mutual (reciprocal) rights and obligations for subjects of international law (Avramov and Kreća, 2003, p. 51-52). International treaties, as the primary instruments for regulating international relations and achieving cooperation between law subjects, must 
have a foothold in international law, which implies that they can not be in conflict with imperative norms of international law (ius cogens). An imperative norm implies "the norm accepted and recognized by the entire international community of states as a norm from which no deviation is permitted and which can not be changed by a new norm of general international law of the same character". Bearing in mind the fact that the main purpose of concluding international treaties and accepting international rules is their application by States within national legal systems, States Parties can not invoke national law provisions to justify the non-execution of a given contract.

International treaties, by common rule, have a relative effect, i.e. contracts are valid only between Contracting Parties. For third countries or international organizations, but also other entities of international law, contracts are pacta tertiis nec nocent nec prosunt - contracts do not create or impose third or any rights or obligations, which is also confirmed by extensive international legal practice. The international courts have confirmed this strictly, that the treaties, whether bilateral or multilateral, impose no obligation on non-Contracting States and that they can not change the rights of these states without their consent (Đorđević, 2007, p. 49-70). This was also confirmed by the Vienna Convention on the Law of Treaties of 1969 and 1986. A clear distinction is made between third countries and third international organizations in relation to contracting parties that may be both States and international organizations. For example, the provisions of the Vienna Convention on the Law of Treaties of 1969 state: "The term Contracting States means a State which agrees to be bound by a treaty, irrespective of whether the treaty has entered into force". Then, it is further stipulated: "The term third country designates a non-contracting party to that contract" (Službeni list SFRJ, 1972). The same is true in the Convention on the Law of Treaties between States and International Organizations or between international organizations since 1986, and refers to international organizations.

An international treaty is a law for a Contracting Party and it must be carried out conscientiously and in good faith. The obligations of the international treaty are fulfilled and are binding only on the contracting parties, and not their members or members of the Organization. It only binds states or international organizations, not directly and their citizens or members of a particular international organization (although in practice, for example, in the event of non-performance of the contract, they often suffer in an indirect way and nationals of the State party or the member state of the international organization). The one-time concluded treaty of a particular State remains in force, regardless of constitutional changes or changes in government that may arise in that State, as long as there is the same subject of international law.

Today, almost every state is in some way a part of an international order consisting of a corpus of international documents and interstate treaties. For example, many countries and ours, in many important aspects of their legal system, give priority to international law in relation to domestic legislation, thereby reducing their sovereignty in a classical sense. Also, membership in an international military organization such as NATO undermines sovereignty understood as a monopoly on the use of force outside the borders of the state, and individual members of the UN Charter and other international acts regarding the protection of human rights can be interpreted as allowing the interference of other states in the internal affairs of a sovereign States without its consent if human rights violate it drastically and to a large extent and in this way question the monopoly on the use of force within the sovereign state itself. 


\section{Some international legal aspects of international treaties as sources of law in regulating international relations in a global environment}

International treaties, by their action in any segment, lead to different bilateral and multilateral ties between states, states and various organizations of economic or other character. This action leads to the creation of a large number of regional economic integration, as well as international governmental and non-governmental economic organizations.

\subsection{International agreements of multilateral character}

A multilateral agreement is an agreement in which more than two contracting parties participate. For example, international agreements of multilateral character define the basic legal rules, which are established in the sphere of foreign investments under the auspices of international organizations. These are, for example: rules constituted within the World Trade Organization, in the part relating to foreign investments (for example: TRIPS - agreement, which regulates the issue of protection of intellectual property rights, etc.); then, the Convention on the Establishment of a Multilateral Investment Guarantee Agency (established with the aim of encouraging inflows of investment into member countries under the auspices of the International Bank for Reconstruction and Development); Convention on the settlement of investment disputes between states and citizens of other countries, etc.

Then, in the post-World War II period, there was a need to create an international economic framework, which would consist of: the International Monetary Fund, the International Bank for Reconstruction and Development and an international organization that would work in the field of trade. In order to draft the future International Trade Organization, in February 1946, the United Nations Resolution on the Establishment of the Preparatory Committee for the UN Conference on Trade and Employment was adopted. At the Second Session of the Preparatory Committee, in April 1947, in Geneva, bilateral negotiations were held on customs conventions. Negotiations have been successfully concluded, and the result is concretized within the General Agreement on Customs and Trade (GATT). GATT was only a temporary, transitional solution for regulating international trade at the multilateral level. Conceived as a temporary trade agreement at the outset, it did not have an institutional structure, but gradually evolved. It was the only multilateral instrument to regulate international trade for forty years, until 1995, when the World Trade Organization (WTO) was established. During the 1970s, and especially during the 1980s, there were such economic changes, which can be said to have significantly compromised the credibility of GATT. Given that these decades have experienced frequent recessions, governments in many countries have resorted to the application of all the many non-tariff barriers to trade in order to protect their economies from coming competition. In addition, they have begun to strengthen the tendencies of establishing regional economic and trade integration, which impede the ability of third countries to access markets, and at the same time violates the principle of liberalization of international trade. The results of the Uruguay Round of negotiations are set out in the Final Act, which was signed on April 15, 1994 in Marrakesh. The Final Act consists 
of the Agreement establishing the World Trade Organization, with the accompanying annexes and the Ministerial Declaration, with a further 25 different decisions. The most important result of these negotiations is the founding of the World Trade Organization, which began on January 1, 2005. The final act was signed by 111 countries, while the agreement on the establishment of the WTO was signed by 104 countries. Among them are: USA, European Union, Japan and Canada, whose countries account for about $90 \%$ of the total world trade in goods and services. The WTO is an international organization that manages multilateral GATT, trade in services (GATS), and TRIPS trade related aspects. Also, the WTO deals with the control of a private business.

More recently, the aspect is placed on the quality of the environment. Access to environmental protection is manifested through the integration of environmental policy into economic and sectoral policies. The basic international treaty regulating issues in this area is the United Nations Framework Convention on Climate Change of 1992 and the Kyoto Protocol, which attempted to make the general obligations (and rights) of the Framework Convention partly concrete and more operative. In addition, in the area of climate change, several other international treaties are also relevant, among which the Vienna Convention for the Protection of the Ozone Layer with the Montreal Protocol on Substances that Deplete the Ozone Layer is of major importance, with several amendments. Due to the complexity of the climate problem, in order to comprehend the international legal aspects more comprehensively, it is necessary to take into account numerous other international and global treaties on protection of the atmosphere, protection and management of water resources, protection of biodiversity, desertification, energy, waste management, hazardous chemicals management, etc. There are also a number of other numerous multilateral agreements in various fields of international law.

The question arises as to how the multilateral agreement works? Are these rules two-fold, or are they only protecting the rich? On the one hand, the World Bank and the International Monetary Fund require developing countries to open the markets as soon as possible, to privatize the economy and to eliminate state subsidies (so-called "shock therapy"), while on the other hand rich countries introduce a number of protectionist measures - agricultural production areas - in order to protect their markets from imports from other countries. Under such rules of the game, the poor countries are condemned to defeat.

The authors of these and similar rules are organizations, banks, industrial giants, wealthy individuals and other lobbyists who lobby for their own interests and in conjunction with influential politicians, make decisions outside the public eye. Their responsibility for world poverty is undoubtedly the greatest. An influential German philosopher, sociologist and professor at the University of Jelly, Tomas Pogi, is the most prominent advocate of the controversial idea that the global economic and political order, the institutions that make up it, as well as the citizens of the countries that support it, are the main culprits for world poverty (Pogi, 2008 ). Some economists accuse Tomas Pogi of failing to take into account local causes of poverty. Residents of many countries live in absolute poverty, because the governments of the tyrannical, political elite are made up of corrupt politicians and military officials, while health and education infrastructure is non-existent. He replied that this charge is not just because it does not negate the local causes of poverty, but only indicates that accountability for the work of the governments of poor countries can often be traced to an international source. However, we can not 
expect the powerful to change politics. Therefore, the real responsibility lies with a citizen who supports such a policy when voting in elections, when he abstains, and when he refuses to politically engage in any other way.

\subsection{International agreements of bilateral character}

A bilateral agreement is an agreement between two states, most often for regulating only one particular issue or case.

Very important bilateral agreements are those in the field of economic relations. Under the Economic Bilateral Agreement is meant the economic relations between the two countries, based on the appropriate forms of mutual cooperation between economic actors from these countries, and in accordance with their interests. These economic relations and forms of cooperation are defined in the affairs of international business and international commercial law. There are also various forms of economic cooperation between the two countries, such as:

Foreign trade, which consists of: import, export, intra-firm trade, "bonded" trade, finishing and processing, leasing, shering, franchising, factoring, forfeiting, re-export and others.

Higher forms of economic cooperation, consisting of: joint ventures, concessions, technology transfer, long-term production cooperation, scientific-technical cooperation, investment projects abroad, feasibility studies, investment project management, incentives and mutual investment protection, and others.

Financial and banking transactions and foreign payment transactions, which include: credit operations, stock exchange operations, foreign debt regulation, international payments, and others.

International Trade Arbitration Activities, which comprise: international trade affairs, ad hoc and institutional arbitration, and others.

In the competition of multilateral and bilateral agreements, that is, when there is a bilateral issue, a question between the two countries is regulated simultaneously by a multilateral agreement, then, in accordance with the lex specialis derogat legi generali rule, a bilateral agreement is applied, with the application of multilateral, if bilaterally directed to it, or if the application of a multilateral contract is more favorable for both parties. This rule of specialty refers to cases where in a certain matter equally applicable to both multilateral and bilateral agreements. However, some new multilateral agreements introduce the rule of exclusive application of their own norms, thus derogating the provisions of the bilateral treaty. Thus, the European Convention on Mutual Assistance in Legal Assistance in Criminal Matters (Article 26, paragraph 1) and the European Prison Extension (Article 28, paragraph 1), all provisions of bilateral treaties, conventions and agreements regulating the field of legal aid and extradition. The derogation would not only apply to provisions governing specific issues, which are not the content of the multilateral convention. In addition, there are no legal impediments that the two countries conclude other bilateral and multilateral agreements between themselves in order to supplement the provisions of the already concluded conventions in order to facilitate the application of the Convention, but not to revise its provisions. 


\subsection{Place and role of international contacts in business process management}

In international traffic, the increasingly important role is played by contracts that are an instrument for regulating and managing business processes in a unique, global economic market.

With the development of international economic relations and international economic relations between business entities and the increased volume of goods and services in international relations, it necessarily led to the development and expansion of a network of increasingly diversified international agreements in this field. They have become the main source of law, which means that they can be the legal basis for regulating certain international economic relations, or they can be the legal basis for resolving certain disputes that may arise in concrete international economic relations.

\subsubsection{International treaties (conventions) - Difficulties in application and unification}

International treaties (conventions), as multilateral international treaties, generally regulate international economic relations, in contrast to bilateral international treaties, which specifically regulate these relations between two particular states.

However, multilateral international treaties (conventions) have a greater significance as sources of international law, if for nothing else, because they are crucial for the unification of law, because as a rule, there is a greater number of states (states) of the treaty. They are the result of the agreement of the will of still the most important subjects in international relations, the state. However, the method of their adoption often imposes insurmountable difficulties in adopting the texts of the contract and requires long deadlines from the idea to the final adoption of the text of the contract, which is not in line with the accelerated international economic development.

Although drafting contracts, as a rule, experts from the relevant fields are engaged, however, their professional work is subject to the political assessment and will of the states, which are authorized and competent to give the final say on the admissibility or inadmissibility of the proposed solutions. However, from the moment of ratification, the Convention becomes a stronger source of rights in relation to domestic regulations and domestic legislation. Without negating the importance of bilateral agreements, it must be borne in mind that they, like all international treaties, represent only the right for the parties, which means that for a relatively small number of countries. Moreover, they can be without major influence on the development of the rules of international law. However, their influence should not be underestimated, as they often provided an incentive to adopt multilateral international conventions, whose solutions are based on rules that are already in place and checked in bilateral agreements.

Often, as a source of rights in the field of international economic and economic relations, international treaties appear not primarily economically, but rather political, but also contain legal norms that apply to these relations (for example, peace treaties, international cooperation agreements and others similar contracts). The great importance of such contracts is that they have a certain, often high significance for the contracting parties, the states that are obligated to apply these rules in their own legislation, or to harmonize their legislation with such contracts. 
International treaties, as a source of rights, bind only countries that have explicitly accepted them, or who have ratified an international agreement containing certain rules. It is understood that in this process, certain differences in the already developed legal culture of different countries, even in the region of the world, but also of different interests, are sometimes difficult to reconcile. J. Vilus, as one of the major difficulties in the process of adopting international treaties, sees the difference between common law, i.e. an Anglo-Saxon legal system characteristic of large economic forces, such as the United States, Great Britain, but also many other states, mainly former colonies under their influence and civil law, the continental legal system, which, in addition to European and Latin American states, includes the former French colonies (Carić, Vilus and Divljak, 2007, p. 55-56). The degree of development of the participating states in the preparation of an international treaty affects the decisions that the contract provides. In this respect, the interests of developed and underdeveloped countries or developing countries are also different. In addition, it should be noted that even when an international treaty has been adopted, it is subject to ratification, ie confirmation in the parliament of the state or another state body, depending on the constitutional regulations of the state. This, as a rule, postpones its entry into force, and sometimes this delay can last for years.

Efforts to eliminate these and similar shortcomings, which came through various proposals for the adoption of international treaties in the UN General Assembly and to be binding on all actors in international economic relations, or that the UN General Assembly recommends that States ratify concluded international treaties, difficult in order to remedy the deficiencies. First of all, because this way of adopting international treaties or adopting recommendations for their ratification, the will of the states is necessary, and on the other hand, the UN General Assembly has no capacity to adopt documents that are the obligation of the states.

In that sense, the best solutions give the unification of rights at the international level. By adopting uniform rules applicable to contracts concluded in various legal, economic and social systems, the removal of obstacles to the conduct of international business transactions contributes to the development of international traffic and the achievement of legal certainty in general. Therefore, the unification of international contract law, and especially the rights of international sales, has become a constant tendency for developed international markets, business people and legal doctrines. The unification of the law would overcome the biggest obstacle in international business transactions, which are very different national legislations, since this is an increasingly intense activity of business entities from different countries participating in international business transactions. This would avoid resolving differences in national legislation based on criteria for conflict resolution (collision method), which are not sufficiently understandable and accessible to the business world, since collision regulations are also national. All this leads to the creation of uncertainty in the international business market. Uniform rules should facilitate the position of contracting parties, provide solutions for every specific legal relationship and more favorable conditions for international trade in goods and services. Also, this would increase the mobility of people, goods, services, capital and information across state borders, which are at the same time the requirements of international business. Therefore, the question of the unification of international treaty law becomes one of the most current issues of the contemporary world.

The advocates of unification are based on the thesis that, by adopting unique legal rules, the space for the emergence of conflicts of law is eliminated, and therefore they 
consider the termination of the need to apply collision norms (Kaczorowska, 1995, p. 6-7). From past experience, it can be said that this is not always so simple and that on the road to real unification, it encounters many difficulties. In order to achieve the highest legal uniformity, it operates through international organizations. Three international documents in this domain are significant: the UN Convention on Contracts for the International Sale of Goods of 1980 (Vienna Convention); UNIDROIT Principles for International Trade Agreements and Principles of European Contract Law, as instruments that significantly contribute to the unification and harmonization of European contract law. There are also special documents that lead to the adoption of the European Civil Code, as a general codification of European civil law.

Sometimes the agreement on equalization of rules is also achieved directly between the interested states. The most common instrument for unification in this form is an international treaty. The agreed text is taken over in the internal law with limited deviation (reserve) and thus ensures a high degree of uniformity. This creates a new corpus of rights - international civil and commercial law. The unified law is sometimes applied to all situations, regardless of whether they have a foreign mark (for example, the Convention on the Unified Bargaining Act of 1930), and sometimes only on situations with a foreign mark (eg the UN Convention on the International Sale of Goods since 1980).

Due to the complexity and complexity of the unification process itself, more recently, the harmonization of rights is increasingly being discussed, in order to emphasize that the absolute uniformity does not concern itself, but rather the convergence of the legal systems. Harmonization consists in reducing the differences and deviations between national legal norms, determining the results that regulation in a particular field needs to achieve, without imposing the means to which it will be specifically achieved, and without imposing the legal text itself. However, in the case of harmonization, there remains room for the application of the collision method.

\section{International treaties in the process of globalization and regionalization}

International treaties in the footsteps follow the processes of globalization and regionalization, as two interconnected and intertwined processes. Regionalization is the connection of two or more economies into appropriate forms of regional integration. Regional economic integrations represent the result of various intergovernmental negotiations, treaties and agreements, the ultimate goal of which is achieving universal economic competitiveness and, as such, are one of the main pillars of economic diplomacy. The basic forms of regional economic integration, arising from various international agreements and contracts are:

- Preferential trade agreement,

- Free Trade Zone,

- customs union,

- a common market,

- unique market (Dašić, 2003). 
The single market represents the most developed form of economic regional integration. In it, the means of payment is only one currency, the unique regulation of the functioning of banks and other institutions (a typical example of the EU).

Processes with increasing intensity in the last two decades, such as: the movement of short-term foreign investments based on a speculative course, long-term foreign direct investment, world trade with a policy of reducing the barriers that would shake, a growing share of transnational corporations in world production and trade, global interdependence of production, the movement of people motivated by trade or job search and the development of new forms of communication have led to the development and increasing influence on the global scene of multinational corporations that dominate world production. The most important among them are: World Trade Organization as the first multilateral organization that has the power to subordinate the will of the national governments to its rules, the Permanent International Criminal Court in progress, regional blocs such as the European Union, ASEAN, NAFTA and political coordination groups at global level G7, G8, G10, G22, G77, OECD). These processes have also led to the development of a global civil society and its new actors, such as international nongovernmental organizations promoting and protecting human rights both internationally and at the UN level as well as at the national and local levels, influencing the spread of a culture of respect human rights, their integration into domestic legislation and the development of international, regional and national mechanisms for their protection. These actors create new rules in international relations, economics, trade and international law. The number of conventions and documents regulating these areas is growing. New multilateral agreements are emerging: trade, intellectual property, communications, etc., and global (UN Millennium Goals) and regional development goals are being agreed at international level. Strengthening awareness of the common destiny of all nations and their connection with the fate of the planet leads to an increase in the number of international agreements on environmental protection at global level (preservation of the ozone layer, preservation of the sea and the oceans, desertification, climate change).

The new stage of globalization, based on new financial markets and rising global service markets, is facilitated by the rapid development of new forms of communication and the development of faster and cheaper rail, road and air traffic. Removing the barrier in trade, economics and transport has also led to the onus of this development - the global linking of socially undesirable and harmful activities, such as international crime, international terrorism, trafficking in women and children, arms and drug trafficking, which leads to the growing importance of international concerted actions of states, the growth of the number of international agreements and conventions in this area, and thus the development of international law.

\section{Conclusion}

We can conclude that globalization as a complex social, economic, cultural, technological, political and geopolitical process has led to enormous mobility of capital and technology, where the organization of ideas and people has gained a growing global and transnational form. Globlization is characterized by an increasing interdependence of national economies with the world economy. Countries in the world are linked to a 
multidimensional network of economic, social and political links. Thanks to profit, as a driving motive of production, it was necessary to create a world market and in that way the largest number of countries and regions of the world would be linked to different forms of mutual economic relations.

The integration of individual countries, especially integration into the European Union, is a significant incentive to these processes, which we can not always influence. But relations of exchange on the world market determine relationships among people and these relations are variable and form beyond the will of people. The daily volume of currency transactions exceeds hundreds of times the amount of real goods and services exchanged. This means that the tendency of separating financial flows from the real sphere of production and trade as a result of the phenomenon of globalization of operations is constantly increasing. National economies increasingly integrate into four fundamental areas - trade, finance, production and a growing network of contracts and institutions. A growing network of treaties connects states to the community with multilateral commitments (such as the G77 group consisting of 132 Member States), regional obligations (the European Union and other trade blocs) and bilateral commitments (eg bilateral tax treaties between the United States and other governments). These actors create new rules in international relations, economics, trade and international law. The number of conventions and other international treaties regulating these areas is growing.

When it comes to transitional economies, one of the key elements of their transition is their reintegration into the world economy through trade, financial flows and other elements. For countries in transition, the only way to avoid isolation and permanent lagging behind is the active attitude towards these changes in order to maximize possible positive effects and minimize possible negative consequences of globalization. Countries in transition can see their chance in various economic and other integrations with neighboring countries as well as developed countries of the world, and are guided by their foreign policy and external economic priorities.

If we start from the basic idea that by removing barriers to trade, investing in technology and improving communication, we will drastically reduce conflicts among nations and thus contribute to peace and progress, we come to the idea of creating a new kind of globalization called "sustainable", which contributes to the development of business and free and has a productive impact on developed countries and developing countries. "Sustainable" globalization highlights the significance of the social context - free societies are able to achieve a faster and more efficient growth of the standard of living, economy and free determination of the individual: free spirit, free market and free entrepreneurship.

The great importance of international treaties in regulating international relations, especially business-economic, is reflected in their use as an instrument of unification. Namely, the biggest obstacle in international business traffic is the very different national legislation and the application of collision method, which is not comprehensible enough for the business world. However, the use of international treaties for this purpose has certain shortcomings. Firstly, it is difficult to reach agreement on substantive legal solutions, given the starting differences in legal systems, language barriers and different interests of states. Representatives of many countries, especially those with great power and influence, come to international negotiations with a deep-seated belief in the superiority 
of one's own rights. They are very much in favor of unification until the uniform text to be adopted resembles their national law. Work on the text that will later be the subject of adoption at an international conference or within an international organization takes place in the cumbersome working bodies and is often ineffective. Often it happens that in order to reach a compromise between the participants, an imprecise formulation will be adopted for certain controversial issues, or that reserves should be allowed.

When the text of the international treaty is finally adopted, there will be a process of ratification and ratification by the competent authorities of the Member States. A number of ratifications are needed to get the treaty into force and this process usually takes several years, and sometimes it is completely absent. Numerous examples of socalled dead conventions testify to the vain efforts and work of experts in international and comparative law. Finally, efforts aimed at fostering unification can be easily disrupted by the different practices of the courts and other authorities of the member states in the application and interpretation of the uniform text. Given that in most cases

\section{References}

Avramov, S. and Kreća, M. (2003). Međunarodno javno pravo, Beograd.

Bečka konvencija o pravu ugovora iz 1969. godine: http://projuris.org/beckakonvencija-o-ugovornom-pravu-1969

Carić, S., Vilus, J. and Đurđev, D. (2007). Međunarodno poslovno pravo, Univerzitet Privredna akademija, Pravni fakultet, Novi Sad.

Dašić, D. (2003). Diplomatija - Ekonomska multilaterala i bilaterala, Fakultet za trgovinu i bankarstvo "Janićije i Danica Karićc", Beograd.

Dašić, D. (2005). Principi internacionalne ekonomije, Fakultet za trgovinu i bankarstvo "Janićije i Danica Karić", Beograd.

Đorđević, M. (2015). Unifikacija i harmonizacija prava međunarodne prodaje, master rad, Pravni fakultet, Niš.

Đorđević, S. (2007). Dejstvo međunarodnih ugovora, Beograd.

Đurović, R. (2004). Međunarodno privredno pravo, Pravni fakultet, Beograd.

Gaverdovskij, A. (1980). Implementacija normi međunarodnog prava, Kijev.

Kaczorowska, A. (1995). International Trade Conventions and Their Effectiveness: Present and Future (International Economic Development Law), Springer.

Kapor, P. (2007). Međunarodni komercijalni i finansijski ugovori i poslovi, Poslovni biro, Beograd.

Kosovac, M. (2004). Tipski ugovori međunarodne kupoprodaje, Želnid, Beograd.

Kostadinović, S. (2005) Međunarodno privredno pravo, Ekonomski fakultet u Subotici, Subotica.

Lando, O. and Beale, H. (2000). Principles Contract Law, Kluwer Law International, The Hague - London-Boston.

Međunarodni ugovori, Službeni list SFRJ, broj 30/1972). 
Milić, T. (2016). Značaj odluka Saveta bezbednosti Ujedinjenih nacijau razvoju međunarodnih pravilao regulisnju upotreba sile u međunarodnim odnosima, doktorska disertacija, Fakultet političkih nauka, Beograd.

Pogi, T. (2008). World Poverty and Human Rights, secound edition, Cambridge: Polity Press.

Simeunović, D. (2009). Nacija i globalizacija, Zograf, Niš.

Simić, D. (2009). Svetska politika, Fakultet političkih nauka, Čigoja štampa, Beograd.

Simić, D. (2012). Rasprava o poretku, Zavod za udžbenike, Beograd.

Smith, S. and Baylis, J. (2001). the Globalization of World Politics, Oxford University Press.

Stefanović, Z. (2014). Pravo Evropske Unije, Pravni fakultet Univerziteta Union, Beograd.

Stefanović, Z. (2015). Kompanijsko pravo, Pravni fakultet Univerziteta Union, Beograd.

Stiglic, Dž. (2002). Protivrečnosti globalizacije, SBM-X, Beograd.

Yeomin, Z. (2002). Ekonomska evolucija: globalizacija dve hiljade godina stvaranja, Računovodstvo/septembar, Časopis za računovodstvo, reviziju i poslovne finansije, Beograd.

Јеротијевић, 3. and Палевић, М., (2016). Равнотежа снага-безбедносни концепт међународне заједнице, in: journal Економика, по. 1, Ниш. 